\title{
Factors Associated with Intention to Donate Hematopoietic Stem Cells among Blood Donors
}

\author{
Chuo Yew Ting a,b Yew Fong Lee ${ }^{c, d}$ Chien Joo Lim ${ }^{\mathrm{e}}$ Rachel Sing Kiat Ting ${ }^{f}$ \\ Mohammad Masrin MD Zahring ${ }^{g}$ Abu Sufian Ahmad ${ }^{\text {h }}$ Jack Siew Yu Wong ${ }^{i}$ \\ Masita Arip ${ }^{j}$ Zubaidah Zakariaj Shahren Ahmad Zaidi Adruce ${ }^{k}$ \\ Jessie Koh Sing Tnay ${ }^{b}$ Yi Shen Wong ${ }^{g}$ \\ aPharmacy Practice and Development Division, Sarawak State Health Department, Ministry of Health, \\ Kuching, Malaysia; ' Institute of Borneo Studies, Universiti Malalysia Sarawak, Kota Samarahan, Malaysia; \\ 'Institute of Global Health, Faculty of Medicine, University of Geneva, Geneva, Switzerland; ${ }^{d}$ Ministry of Health, \\ Putrajaya, Malaysia; ${ }^{e}$ Clinical Research and Innovation Office, Tan Tock Seng Hospital, Singapore, Singapore; \\ f Jeffrey Cheah School of Medicine and Health Sciences, Monash University, Selangor, Malaysia; ${ }^{9}$ Blood Transfusion \\ Services and Blood Bank Department, Sarawak General Hospital, Ministry of Health, Kuching, Malaysia; \\ hBlood Transfusion Services and Blood Bank Unit, Sibu Hospital, Ministry of Health, Sibu, Malaysia; 'Hospital Miri, \\ Ministry of Health, Miri, Malaysia; ${ }^{j}$ nstitute for Medical Research, Ministry of Health, Kuala Lumpur, Malaysia; \\ ${ }^{k}$ Faculty of Cognitive Sciences and Human Development, Universiti Malalysia Sarawak, Kota Samarahan, Malaysia
}

\section{Keywords}

Blood donors - Donate · Hematopoietic stem cells . Intention

\begin{abstract}
Introduction: Past studies pay little attention to the intention to donate hematopoietic stem cells (HSC) among blood donors. This study investigated the level of and the influence of socio-demographic characteristics, knowledge, attitude, subjective norm and self-efficacy on the intention to donate HSC among blood donors. Methods: This cross-sectional study recruited blood donors at selected public hospitals in the Malaysian State of Sarawak in 2019. A structured questionnaire was developed based on the review of relevant literature. It gathered information on socio-demographic characteristics, knowledge, attitude, subjective norm and self-efficacy on the intention to donate HSC. Variables with a $p$ value $<0.200$ in bivariate analysis were included in the variable selection for regression modeling to examine their associations with the intention to donate HSC. Results: A to-
\end{abstract}

tal of 569 blood donors participated (94.5\% response rate). Overall, $87.1 \%$ reported a positive intention to donate HSC. In the regression model, the factor with the greatest association with intention to donate HSC was subjective norms about HSC donation ( $\beta=0.35,95 \% \mathrm{Cl} 0.27-0.42$ ), followed by attitude about regulations of HSC donation ( $\beta=0.21,95 \%$ $\mathrm{Cl} 0.13-0.35)$, self-efficacy on HSC donation $(\beta=0.15,95 \% \mathrm{Cl}$ 0.09-0.32), attitude about the potential side effects of HSC donation $(\beta=0.14,95 \% \mathrm{Cl} 0.02-0.10)$ and highest education level $(\beta=0.10,95 \% \mathrm{Cl} 0.03-0.44)$. Conclusions: The findings can be used to formulate a better strategy in promoting HSC donation among blood donors in the region.

(c) 2020 S. Karger AG, Basel

\section{Introduction}

In light of its promising effects and being the only available choice in treating certain diseases, hematopoietic stem cell transplantation (HSCT) has steadily gained popularity around the globe in the past decade [1]. As the 
positive outcomes of HSCT in treating diseases greatly relies on the matching of human leukocyte antigens (HLA) between the donors and recipients [2], the recruiting of matched unrelated donors (MUD) from the same region as the patients is highly desirable. In Malaysia, the HSCT with HSC from MUD reached its milestone in 2000 by establishing a national stem cell donors registry called the "Malaysian Stem Cell Registry" (MSCR), to provide a large pool of HSC volunteered donors [3]. As of September 2017, there were 29,300 (73.25\%) registered HSC donors. However, only 572 (1.95\%) were of Sarawak ethnicity [4]. In addition, the composition of Sarawak ethnicities is different from Peninsular Malaysia and it was diversified $[5,6]$, thus the pool of registered HSC does not reflect the mixed ethnic composition of the Sarawak population. Specifically, the largest ethnic group in Sarawak is the "Sea Dayaks" - Ibans, followed by Malays, Chinese, "Land Dayaks" - Bidayuh, and others [7]. This is different from the composition of the west Malaysia and Malaysia as a whole, where Malay is the largest ethnic group, followed by Chinese, Indian and others [8]. Moreover, intermarriages across ethnic groups have been common in the state [9]. As a result, the low registration rate as HSC donors in Sarawak will further decrease the chance of having MUD in local patients.

As registering as a HSC donor in most countries is completely voluntary, it is crucial for health practitioners to know the factors that drive the intention to donate HSC among general public. This study aimed to investigate the level of and the influence of socio-demographic characteristics, knowledge, attitude, subjective norm and self-efficacy on intention to donate HSC among blood donors in Sarawak.

\section{Materials and Methods}

This was a cross-sectional study conducted at selected public hospitals in the Malaysian State of Sarawak, from May 1, 2019 to August 31, 2019. Approval from Medical Research Ethics Committee of Ministry of Health, Malaysia was obtained on June 12, 2018 (Approval letter ref. no.: KKM.NIHSEC.P18-1241[5]). Blood donors who completed their blood donation at the selected public hospitals during the study period were invited and consented for participation. Blood donors who were excluded were those who: (1) could not read or understand Malay or English; (2) required immediate medical attention due to unexpected adverse events incurred by blood donation; (3) declared that they had filled the same questionnaire before; or (4) declined the consent to participate.

The hypothesis of the study was that half of the respondents have positive intention to donate HSC. As such, the proportion of blood donors' who intend to donate HSC was estimated to be $50 \%$ for sample size calculation. With the margin of error and confidence level pre-set to 5 and $95 \%$, respectively, the minimum sample size required was 385 [10]. By estimating a response rate of $70 \%$ before the study, the targeted sample size was 552. In order to generalise the results to all blood donors registered with public hospi-
Table 1. Socio-demographic and HSC donation-related characteristics of the respondents and their correlation with intention to donate HSCs $(n=569)$

\begin{tabular}{|c|c|c|}
\hline Respondents' characteristics & $N(\%)$ & $\begin{array}{l}\mathrm{t} / \mathrm{F} \text { value; } \\
p \text { value }\end{array}$ \\
\hline \multicolumn{3}{|c|}{ Socio-demographic characteristics } \\
\hline \multicolumn{3}{|c|}{ Age in years } \\
\hline Mean (SD) & $34.6(9.97)$ & \\
\hline $18-50$ & $530(93.1)$ & -1.91 \\
\hline$>50$ & $39(6.9)$ & $0.057^{\mathrm{a}}$ \\
\hline \multicolumn{3}{|l|}{ Gender } \\
\hline Male & $394(69.2)$ & -1.18 \\
\hline Female & $175(30.8)$ & $0.239^{\mathrm{a}}$ \\
\hline \multicolumn{3}{|l|}{ Ethnicity } \\
\hline Malay & $201(35.3)$ & 1.23 \\
\hline Iban & $73(12.8)$ & $0.175^{\mathrm{b}}$ \\
\hline Bidayuh & $36(6.3)$ & \\
\hline Chinese & $198(34.8)$ & \\
\hline Indian & $8(1.4)$ & \\
\hline Others & $53(9.3)$ & \\
\hline \multicolumn{3}{|l|}{ Educational level } \\
\hline No formal education & $4(0.7)$ & 1.36 \\
\hline Primary school & $15(2.7)$ & $0.087^{\mathrm{b}}$ \\
\hline Secondary school & $259(46.0)$ & \\
\hline Tertiary & $285(50.6)$ & \\
\hline \multicolumn{3}{|c|}{ HSC donation-related characteristics } \\
\hline \multicolumn{3}{|c|}{ Registered with MSCR } \\
\hline Yes & $26(4.6)$ & 0.14 \\
\hline No & $525(95.3)$ & $0.890^{\mathrm{a}}$ \\
\hline \multicolumn{3}{|l|}{ Past donation of HSC } \\
\hline Yes & $7(1.3)$ & -0.42 \\
\hline No & $547(98.7)$ & $0.674^{\mathrm{a}}$ \\
\hline \multicolumn{3}{|c|}{ Attended any promotion related to HSC donation } \\
\hline Yes & $25(4.5)$ & -0.77 \\
\hline No & $535(95.5)$ & $0.444^{\mathrm{a}}$ \\
\hline
\end{tabular}

${ }^{\text {a }}$ Independent $t$ test. ${ }^{\mathrm{b}}$ ANOVA test. HSC, hematopoietic stem cell; MSCR, Malaysian stem cell registry; SD, standard deviation; $\mathrm{t} / \mathrm{F}$ value, $t$ statistics value for independent $t$ test, $\mathrm{F}$ statistics value for ANOVA test.

tals in the Malaysian State of Sarawak, the cumulative relative frequency method of probability proportional to size sampling method was employed $[11,12]$. Based on the sampling method, the public hospitals sampled were Miri Hospital, Sibu Hospital and Sarawak General Hospital (online suppl. material 1; for all online suppl. material, see www.karger.com/doi/10.1159/000512197). Notably, Sarawak General Hospital is a tertiary public hospital located at the southern zone of Sarawak State. As for Sibu Hospital and Miri Hospital, they are located at the central zone and northern zone of Sarawak State, respectively.

The instrument used in this study is a self-administered, paperbased, structured questionnaire. The items of the questionnaire are developed based on the review of relevant literatures [13-23]. The questionnaire has 6 sections (online suppl. material 2). The first section contains the questions on sociodemographic characteristics (age, gender, ethnicity and education level) and their HSC donation-related characteristics (registration with MSCR, donated HSC before and attended any promotion related to HSC donation). The second section has 4 statements to measure knowledge about HSC 
Table 2. Knowledge about HSC donation and correlation with intention to donate HSC $(n=569)$

\begin{tabular}{|c|c|c|c|c|c|c|}
\hline \multicolumn{2}{|c|}{ Questions } & \multirow{2}{*}{$\begin{array}{l}\text { Correct } \\
\text { answer }\end{array}$} & \multirow{2}{*}{$\begin{array}{l}\text { Correct } \\
\text { response (\%) }\end{array}$} & \multirow{2}{*}{$\begin{array}{l}\text { Coefficient } \\
0.411\end{array}$} & \multirow{2}{*}{$\begin{array}{l}95 \% \mathrm{CI} \\
0.171,0.652\end{array}$} & \multirow{2}{*}{$p$ value } \\
\hline $\mathrm{K} 1$ & $\begin{array}{l}\text { Before I am able to donate stem cells, I must register with } \\
\text { Malaysian stem cell registry }(n=567)\end{array}$ & & & & & \\
\hline $\mathrm{K} 2$ & $\begin{array}{l}\text { After you have registered as stem cells donor, you cannot } \\
\text { withdraw when you are requested to donate stem cells because } \\
\text { legal actions will be taken against you }(n=563)\end{array}$ & False & $209(37.1)$ & 0.227 & $-0.016,0.470$ & $0.067^{\mathrm{a}}$ \\
\hline $\mathrm{K} 3$ & $\begin{array}{l}\text { The side effects of stem cell donations will remain forever after } \\
\text { donating stem cells }(n=567)\end{array}$ & False & $115(20.3)$ & 0.062 & $-0.182,0.307$ & $0.616^{\mathrm{a}}$ \\
\hline \multirow[t]{2}{*}{ K4 } & $\begin{array}{l}\text { The risks of potential side effects experienced by bone } \\
\text { marrow stem cell donors are lesser than in peripheral } \\
\text { blood stem cell donors }(n=566)\end{array}$ & False & $51(9.0)$ & -0.134 & $-0.626,0.358$ & $0.594^{\mathrm{a}}$ \\
\hline & Average percentage of correct response (\%) & $31.5( \pm$ & 84) & & & \\
\hline
\end{tabular}

${ }^{a}$ Linear regression. CI, Confidence interval.

donations. The third section has 10 statements to measure attitude about HSC donation. Specifically, 3 dimensions of their attitude towards the HSC donation were measured, namely attitude towards regulations of HSC donation (3 statements), attitude towards the handling of HSC donation (5 statements) and attitude towards the potential side effects of HSC donation (2 statements). The fourth section has 3 statements to measure subjective norms towards HSC donations. The sixth section has 3 statements to measure intention to donate HSC. In particular, 2 dimensions of the intention to donate HSC were measured: the intention to register as a HSC donor (3 statements), and the intention to donate HSC if their stem cells were found to be matching with certain patient(s) ( 3 statements). Apart from section 1 and 2, the answers to the statements of the other sections were 7 points Likert-scale, with 1 indicating strong disagreement and 7 indicating strong agreement.

The questionnaire was pre-tested among 5 blood donors and pilot tested among 50 blood donors who joined the blood donation campaign organised by a non-government organisation. The Cronbach's alpha values for the constructs knowledge, attitude, subjective norms, self-efficacy and intention to donate were 0.59 , $0.72,0.72,0.82$ and 0.96 , respectively.

Data collected was entered, cleaned and analysed using SPSS version 19.0 (IBM Corp, Armonk, NY, USA) and STATA (version 13.1, StataCorp LP, College Station, TX, USA). The demographic characteristics and responses of the questionnaire were summarised as the mean and SD or frequency and percentage. The missing data were found to be missing at random and thus the complete case analysis approach was employed. The independent $t$ test or ANOVA was used to examine the association between socio-demographic characteristics and intention to donate HSC. The simple linear regression was used to explore the associations between individual knowledge questions with intention to donate HSC. The Pearson correlation test was employed to examine the association between attitude, subjective norms and self-efficacy with intention to donate HSC. Variables with a $p$ value $<0.200$ in bivariate analysis were included in the variable selection for multiple linear regression modelling using the enter method to examine their associations with intention to donate HSC. All tests were 2 sided and a $p$ value $<0.05$ was considered statistically significant.

\section{Results}

A total of 602 blood donors from study sites were approached during the study period and 569 responded, yielding a $94.5 \%$ response rate. The majority of the respondents were from Sarawak General Hospital $(n=301$, $52.9 \%)$, followed by Miri Hospital $(n=138,24.3 \%)$ and Sibu Hospital ( $n=130,22.8 \%)$. The socio-demographic characteristics of the respondents are shown in Table 1. Notably, the majority were male (69.2\%), aged between 18 and 50 years $(93.1 \%)$, with a mean age of 34.6 years (SD 9.97), Malay ethnicity (35.3\%) and tertiary education as their highest education level (50.6\%). In terms of HSC and blood donation related characteristics, most were not registered with MSCR (95.3\%), had not donated HSC before $(98.7 \%)$ and were not exposed to any HSC campaign $(95.5 \%)$. None of these characteristics were significantly associated with the intention to donate HSC.

It was found that the average correct response rate among all respondents was $31.5 \%$ ( \pm 27.84 ; Table 2$)$. The question with the lowest correct response is about the different risk of potential side effects between bone marrow stem cell donors and peripheral blood stem cell donors (9.0\%). On the other hand, the question with the most correct responses is about the requirement for registration with MSCR prior to HSC donation (59.4\%). Among the 4 questions related to knowledge, only the knowledge about the compulsory registration with MSCR prior to HSC donation was significantly correlated with intention to donate HSC (coefficient $=0.411 ; p<0.001$; Table 2).

All 3 dimensions of attitude towards HSC donation were found to be significantly correlated with HSC donation ( $p<0.01$; Table 3$)$. The attitude about the lawfulness of HSC donation showed the strongest correlation with 
Table 3. Attitude, subjective norm and self-efficacy of the participants about HSC donation and their correlations with intention to donate HSC $(n=569)$

\begin{tabular}{|c|c|c|}
\hline $\begin{array}{l}\text { Questions (scoring range is } 1 \text { to } 7,1 \text { indicates strongly } \\
\text { disagree; } 7 \text { indicates strongly agree) }\end{array}$ & Mean (SD) & $\begin{array}{l}\text { Pearson correlation } \\
\text { coefficient; } p \text { value }\end{array}$ \\
\hline \multicolumn{3}{|l|}{ Attitude dimensions } \\
\hline Attitude about the lawfulness of HSC donation $(n=567)$ & $5.5(1.23)$ & $0.305 ;<0.001$ \\
\hline 1 Stem cell donation is against my religious doctrine & $2.60(1.95)$ & \\
\hline 2 Stem cell donation is ethical & $5.48(1.60)$ & \\
\hline 3 Stem cell donation is regulated according to laws & $5.53(1.64)$ & \\
\hline Attitude about the handling of the HSC donation $(n=567)$ & $6.1(1.19)$ & $0.276 ;<0.001$ \\
\hline 4 Stem cell donation authority will assure that the stem cells donated will not be misused & $5.78(1.41)$ & \\
\hline 5 Stem cell donation is handled by a group of qualified and trained experts & $6.19(1.25)$ & \\
\hline $\begin{array}{l}\text { Stem cell donation authority will ensure all personal information disclosed } \\
\text { will be strictly confidential }\end{array}$ & $6.10(1.34)$ & \\
\hline $\begin{array}{l}7 \text { Stem cell donation authority will govern my rights as a voluntary donor } \\
\text { without imposing any threat, rewards or force }\end{array}$ & $6.13(1.34)$ & \\
\hline $\begin{array}{l}8 \text { Stem cell donation authority will ensure the donors are provided with all } \\
\text { relevant information including the risk and potential side effects }\end{array}$ & $6.18(1.30)$ & \\
\hline Attitude about the potential side effects of the HSC donation $(n=564)$ & $6.2(3.32)$ & $0.130 ;<0.01$ \\
\hline 9 The stem cell donation process is painful & $4.98(1.73)$ & \\
\hline 10 Stem cell donation would incur side effects to my health & $4.83(1.78)$ & \\
\hline Overall mean $( \pm S D)^{\mathrm{a}}$ & $5.3(0.88)$ & \\
\hline \multicolumn{3}{|l|}{ Subjective norm about the HSC donation } \\
\hline 11 Most people who I know will encourage me to donate & $4.53(1.56)$ & \\
\hline 12 Most of the people that I know have donated & $3.80(1.77)$ & \\
\hline 13 I have been encouraged to donate & $4.10(1.77)$ & \\
\hline Overall mean $( \pm \mathrm{SD})$ & $4.15(1.43)$ & $0.319 ;<0.001$ \\
\hline \multicolumn{3}{|l|}{ Self-efficacy on HSC donation } \\
\hline 14 I feel easy to donate & $5.03(1.64)$ & \\
\hline 15 It is very troublesome for me to donate & $3.65(1.77)$ & \\
\hline 16 I need to make many efforts to donate & $4.59(1.76)$ & \\
\hline Overall mean $( \pm S D)^{\mathrm{b}}$ & $4.3(1.07)$ & $0.241 ;<0.001$ \\
\hline
\end{tabular}

a The questions number $1,9,10$ are reverse coded before calculating the overall mean $( \pm \mathrm{SD}) .{ }^{\mathrm{b}}$ The questions number 15 and 16 are reverse coded before calculating the overall mean $( \pm$ SD). HSC, hematopoietic stem cell.

intention to donate HSC (coefficient $=0.305$ ), followed by attitude about the procedures of the HSC donation (coefficient $=0.276$ ), and attitude about the potential side effects of the HSC donation was found to be significantly correlated with intention to donate HSC (coefficient = 0.130; Table 3). Nonetheless, the subjective norm about and self-efficacy of the HSC donation were also found to be significantly correlated with intention to donate HSC $(p<0.001$; Table 3$)$.

In terms of intention to donate, it was found that the level of intention to register as a HSC donor (mean $=5.0$, $\mathrm{SD}=1.49)$ and intention to donate HSC if their stem cells were found to match with a patient $($ mean $=5.0, \mathrm{SD}=1.43$ ) were similar (Table 4 ). Overall, $87.1 \%$ reported a positive intention to donate HSC (having a mean between 4 and 7, indicating agreement to strong agreement), with an average level of intention to donate HSC of $4.9(\mathrm{SD}=1.41)$.

In the multiple linear regression model, 5 factors were found to be significantly and positively associated with the intention to donate HSC (Table 5). The factor with the greatest association with intention to donate HSC was subjective norms about HSC donation $(\beta=0.35,95 \%$ CI $0.27-0.42$ ), followed by attitude about lawfulness of HSC donation ( $\beta=0.21,95 \%$ CI $0.13-0.35)$, self-efficacy on HSC donation ( $\beta=0.15,95 \%$ CI $0.09-0.32)$, attitude about the potential side effects of HSC donation $(\beta=0.14$, $95 \%$ CI $0.02-0.10)$ and highest education level $(\beta=0.10$, 95\% CI 0.03-0.44).

\section{Discussion/Conclusion}

Past studies revealed that blood donors have greater willingness to donate urological tissue compared to nonblood donors [24], and being a blood donor is a positive predictor for participation in HSC donation [13-15]. Notably, there were 11 past studies related to HSC donation conducted in countries including Korea [16], Hong Kong 
Table 4. Intention to donate HSC, which comprised of intention to register as a HSC donor and intention to donate if their stem cells were found to be matching with a patient $(n=569)$

Questions (scoring range is 1 to 7, 1 indicates strong disagreement;

Mean (SD)

7 indicates strong agreement)

My intention to register as a HSC donor...

1 I intend to register as a HCS donor

$4.99(1.61)$

I intend to find out on how to register as HSC donor

3 I still intend to register as a HSC donor even though someone close might influence me against it

$5.05(1.56)$

Mean (SD)

Intention to donate HSC if your stem cells were found to be matching with a patient...

4 I still intend to donate my stem cells

5 I still intend to donate even though someone close might influence me against it

I am willing to embrace all the challenges including the risk of side effects to ensure the patient(s) who needs my stem

cells would get my stem cells

Mean (SD)

$4.77(1.62)$

Overall mean (SD) for intention to donate (questions 1 to 6)

* $87.1 \%$ reported a positive intention to donate HSC (having a mean between 4 and 7 , indicating agreement to strong agreement).

Table 5. Multiple linear regression for variables related to intention to donate HSC $(n=520)$

\begin{tabular}{|c|c|c|c|c|}
\hline \multirow[t]{2}{*}{ Outcome } & \multirow[t]{2}{*}{ Independent variables ${ }^{a}$} & \multicolumn{3}{|c|}{ Multiple linear regression ${ }^{b, c}$} \\
\hline & & Std. coeff. & $95 \% \mathrm{CI}$ & $p$ value \\
\hline \multirow[t]{9}{*}{$\begin{array}{l}\text { Intention to } \\
\text { donate HSC }\end{array}$} & $\begin{array}{l}\text { Knowledge towards compulsory registration as } \\
\text { HSC donor prior to donation }\end{array}$ & 0.03 & -0.15 to 0.30 & 0.526 \\
\hline & Attitude about regulations of HSC donation & 0.21 & 0.13 to 0.35 & $<0.001$ \\
\hline & Attitude about handling of HSC donation & 0.09 & -0.01 to 0.22 & 0.067 \\
\hline & $\begin{array}{l}\text { Attitude about the potential side effects of HSC } \\
\text { donation }\end{array}$ & 0.14 & 0.02 to 0.10 & 0.001 \\
\hline & Subjective norms about HSC donation & 0.35 & 0.27 to 0.42 & $<0.001$ \\
\hline & Self-efficacy on HSC donation & 0.15 & 0.09 to 0.32 & $<0.001$ \\
\hline & Age of respondents & 0.06 & -0.002 to 0.02 & 0.127 \\
\hline & Highest education level & 0.10 & 0.03 to 0.44 & 0.026 \\
\hline & Ethnicity & 0.05 & -0.02 to 0.11 & 0.185 \\
\hline
\end{tabular}

${ }^{\text {a }}$ Variables with $p$ value $<0.200$ in univariate analysis were included into the multivariate model using enter method. ${ }^{\mathrm{b}}$ Multicollinearity was checked and not found (variance inflation factor $<3$ ); normality of residuals was checked (using histogram and normal P-P plot of regression standardized residual) and found fulfilled. ${ }^{\mathrm{c}} \mathrm{R}$ square equals to $0.279(\mathrm{SE}=1.20)$; intercept $(95 \% \mathrm{CI})$ equals to $-1.677(-3.04$ to -0.31$)$.

[17], Saudi Arabia [18], Rhode Island [19], India [20], Greek [14], Japan [15], United States [13, 21-23]. Among these 11 studies, 4 were conducted among medical students $[13,16,19,20], 7$ focused solely on bone marrow HSC donation $[14,15,19,21-23]$ or peripheral blood HSC donation [20]. Notably, none focused on both bone marrow HSC and peripheral blood HSC donations among blood donors. Also, none of these studies employed behavioural theories to assist in understanding the contributing factors of intention to donate HSC.

It was found that the knowledge of the respondents was poor. Insufficient knowledge or misconceptions of HSC donation were found to cause attrition of promoting
HSC donation [23]. In fact, such misconceptions about HSC donation apply to every individual who does not have sufficient and correct knowledge, even among people with a medical background [13, 19]. The attitude about the regulations of HSC donation has the strongest correlation with intention to donate HSC. While some may know the purpose of HSC donation, they would still be concerned about whether the overall idea of HSC donation is against their religious beliefs or personal ethical views. The interviews with Buddhist, Hindu and Catholic leaders in Malaysia regarding their ethical views towards human embryonic stem cell research revealed contrasting ethical views among them [25]. Although the ongoing de- 
bates concern the use of human embryos and have nothing to do with HSC donation, such salient controversial issues inevitably influence the attitude of the believers towards any activities related to human stem cells. Our argument is in line with that described by Bongso and Richards [26]: "Although there are fewer moral objections associated with adult stem cell work, the assertion that both adult and embryonic stem cells are equivalent is tenuous".

On the other hand, the subjective norms and self-efficacy towards HSC donation were found to be significantly associated with intention to donate HSC. This supports the proposition of TPB. Also, Kita et al. [15] revealed that having people around you who discuss HSC donation is associated with a greater intention to register as a bone marrow donor.

In terms of intention to donate HSC, it was encouraging to know that the majority of the respondents had positive intentions to donate HSC. For healthcare authorities, professionals or non-profit organisation personnel who aim to promote HSC donation, they should first focus on enhancing the subjective norms about HSC donation, followed by addressing the attitude about regulations of HSC donation, self-efficacy on HSC donation and attitudes about the potential side effects of HSC donation. Nonetheless, as the respondents with higher education levels had greater intentions to donate HSC, the promotion of HSC donation should first target blood donors with a higher education level.

The significance of this study is that it evaluated the intention to donate HSC of a composite ethnic population with different religions. Nonetheless, the findings of this study should be interpreted conservatively. First, this is a cross-sectional study, so the causal effect between the factors contributing to intention to donate could not be concluded. Long-term follow-up of the donor populations is necessary to verify the effects of campaigns for recruitment of MUD. Second, the instrument used in this study has not undergone a comprehensive validation process. Third, this study merely explored the intention to donate HSC rather than their later actual involvement in HSC donation.

Overall, although the knowledge related to HSC donation among the respondents was poor, their levels of at- titude, subjective norms, self-efficacy and their intention to donate HSC were positive and above average. Concerns about the regulations of HSC donation, proper handling of HSC donation and potential side effects of HSC donation must be addressed while promoting HSC donation. The findings are useful for the development of strategies for donor recruitment in the region.

\section{Acknowledgements}

We thank Director General of Health Malaysia for his permission to publish this study. We thank Dr. Marysia Gapin and Dr. Tharani a/p Vedikaran for their assistances in patient recruitment and data collection. We thank Mr. John Ting Sing Chun for his assistance in data entry.

\section{Statement of Ethics}

This study obtained approval from Medical Research Ethics Committee of Ministry of Health, Malaysia on June 12, 2018 (Approval letter ref. no.: KKM.NIHSEC.P18-1241(5)) prior to data collection. Blood donors who completed their blood donation at the selected public hospitals during the study period were invited and provided written consent for participation.

\section{Conflict of Interest Statement}

The authors have no conflicts of interest to declare.

\section{Funding Sources}

No funding was received for this study.

\section{Author Contributions}

C.Y.T., Y.F.L., C.J.L., M.M.M.Z., A.S.A., J.S.Y.W., M.A., Z.Z., S.A.Z.A., J.K.S.T, and Y.S.W. conceptualized, designed and drafted the protocol of the study. C.Y.T. and C.J.L. analysed the data and reported the findings. Y.F.L., M.M.M.Z., J.S.Y.W., R.S.K.T., A.S.A., M.A., Z.Z., and Y.S.W. interpret the data and provide practical implications. C.Y.T. drafted the manuscript. R.S.K.T. critically reviewed the draft of the manuscript. All authors approve the manuscript for publication. Y.S.W., M.M.M.Z., J.S.Y.W., and A.S.A. supervised the execution of the study.

\section{References}

1 Gratwohl A, Baldomero H, Aljurf M, Pasquini MC, Bouzas LF, Yoshimi A, et al.; Worldwide Network of Blood and Marrow Transplantation. Hematopoietic stem cell transplantation: a global perspective. JAMA. 2010 Apr;303(16):1617-24.
2 Lee SJ, Klein J, Haagenson M, Baxter-Lowe LA, Confer DL, Eapen M, et al. High-resolution donor-recipient HLA matching contributes to the success of unrelated donor marrow transplantation. Blood. 2007 Dec;110(13): 4576-83.
3 Ministry of Health Malaysia [Internet]. Malaysian Stem Cell Registry. [cited Feburary 2, 2020]. Available from: https://m.facebook. com/pages/category/Government-Organization/Malaysian-Stem-Cell-Registry349126145435696/. 
4 Lai. Stem cell donation often misunderstood - SCCS [Internet]. BorneoPostOnline. [cited January 18, 2020]. Available from: http:// www.theborneopost.com/2017/11/01/stemcell-donation-often-misunderstood-sccs/.

5 Jehom WJ. Ethnic pluralism and ethnic relations in Sarawak. Akademika. 2002;61(1)

6 BorneoPostOnline [Internet]. Intermarriages common in Julau. [cited January 18, 2020] Available from: http://www.theborneopost. com/2015/06/28/intermarriages-commonin-julau/.

7 Sarawak Government [Internet]. Sarawak Population by District 2017. [cited July 20, 2020]. Available from: https://data.sarawak. gov.my/home/data/resource_download/709.

8 MAMPU [Internet]. Malaysia Information: Demograph of Population. [cited July 25, 2020]. Available from: https://www.malaysia. gov.my/portal/content/30114.

9 Ibrahim Z. Towards a Critical Alternative Scholarship on the Discourse of Representation, Identity and Multiculturalism in Sarawak. InBorneo Studies in History, Society and Culture. Singapore: Springer; 2017. pp. 35-55.

10 Naing L, Winn T, Rusli BN. Practical issues in calculating the sample size for prevalence studies. Arch Orofac Sci. 2006;1:9-14.

11 World Health Organization [Internet]. Steps in applying Probability Proportional to Size (PPS) and calculating Basic Probability Weights. [cited July 22, 2019]. Available from http://www.who.int/tb/advisory_bodies/im- pact_measurement_taskforce/meetings/ prevalence_survey/psws_probability_prop_ size_bierrenbach.pdf.

12 Abdulla F, Hossain M, Rahman M. On the selection of samples in probability proportional to size sampling: cumulative relative frequency method. Math Theor Model. 2014;4(6): 102 Á7.

13 Narayanan P, Wolanskyj A, Ehlers SL, Litzow MR, Patnaik MS, Hogan WJ, et al. Medical students' knowledge, familiarity, and attitudes towards hematopoietic stem cell donation: stem cell donation behaviors. Biol Blood Marrow Transplant. 2016 Sep;22(9):1710-6.

14 Galanis PA, Sparos LD, Katostaras T, Velonakis E, Kalokerinou A. Factors that influence Greeks' decision to register as potential bone marrow donors. Transplant Proc. 2008 Jun; 40(5):1271-4.

15 Kita Y, Ueshima H, Okayama A, Yamakawa M. [Factors influencing self-registration in a bone-marrow bank: analysis of data from a population survey in Shiga Prefecture] [Nihon koshu eisei zasshi]. Nihon Koshu Eisei Zasshi. 1993 Nov;40(11):1038-46.

16 Kim M, Ahn H. Student Nurses' Knowledge, Attitude, and Intention for Hematopoietic Stem Cell Donation in Korea. Adv In Sci Serv Sci. 2013;5:145.

17 Kwok J, Leung E, Wong W, Leung K, Lee CK, Lam W, et al. Factors Influencing Hematopoietic Stem Cell Donation Intention in Hong Kong: A Web-Based Survey. Ann Transplant. 2015 Oct;20:604-13.
18 Abdrbo A, Hassanein S, Albajhan G, Alsabi F. Factors Influencing Hematopoietic Stem Cell Donation. J Nurs Health Sci. 2017;6:54-61.

19 Vasconcellos A, Nunes A, Feller E. Knowledge, attitudes, and behaviors regarding the bone marrow registry among college and medical students in Rhode Island. Med Health R I. 2011 Oct;94(10):302-5.

20 Varghese ST, Hem M. Peripheral blood stem cell donation awareness among college students. Int J Sci Technol Manag. 2015;4:1-5.

21 Briggs NC, Piliavin JA, Lorentzen D, Becker GA. On willingness to be a bone marrow donor. Transfusion. 1986 Jul-Aug;26(4):324-30.

22 Glasgow ME, Bello G. Bone marrow donation: factors influencing intentions in African Americans. InOncology Nursing Forum; 2007. p. 34.

23 Switzer GE, Myaskovsky L, Goycoolea JM, Dew MA, Confer DL, King R. Factors associated with ambivalence about bone marrow donation among newly recruited unrelated potential donors. Transplantation. 2003 May; 75(9):1517-23.

24 McKenzie KD, Fitzpatrick PE, Sheehan JD. Tissue banking: relationship with blood donor and organ donor card status. ISRN Urol. 2012;2012:475729.

25 Sivaraman MA, Noor SN. Human embryonic stem cell research: ethical views of Buddhist, Hindu and Catholic Leaders in Malaysia. Sci Eng Ethics. 2016 Apr;22(2):467-85.

26 Bongso A, Richards M. History and perspective of stem cell research. Best Pract Res Clin Obstet Gynaecol. 2004 Dec;18(6):827-42. 